\title{
Rekonsepsi Perlindungan Hukum Atas Magic dalam Perspektif Hukum Hak Cipta di Indonesia
}

\author{
Ayu Mustika Pamungkas
}

Ayu Mustika Pamungkas; Magister Ilmu Hukum; Universitas Brawijaya; Jalan MT. Haryono No.169; Malang; Jawa Timur.

\section{ARTICLEINFO}

Article history:

Received 2019-05-09

Received in revised form

2019-06-19

Accepted 2019-07-01

\section{Kata kunci:}

Rekonsepsi; Perlindungan Hukum;

Magic; Hak Cipta.

\section{Keywords:}

Reconception; Legal Protection;

Magic; Copyright.

DOI: https://doi.org/10.26905/

idjch.v10i2.3199.

\section{Abstrak}

Pembatasan bentuk ciptaan yang dilindungi dalam udang-undang hak cipta berakibat status karya magic sulit dikategorikan walaupun dalam perkembangannya magic seringnya dikategorikan berbentuk drama atau koreografi, namun elemen-elemen pada bentuk tersebut tidak merepresentasikan magic. Perlindungan diperlukan karena terjadinya kasus pemaparan atas trik magic, sedangkan hukum hak cipta tidak melindungi ciptaan berbentuk metode. Hal ini tentu menjadi kekosongan hukum. Tujuan penelitian ini menganalisis rekonsepsi perlindungan hukum yang tepat sasaran atas magic. Penelitian ini merupakan penelitian yuridis normatif dengan pendekatan perundang-undang, konseptual, dan komparatif. Hasil penelitian berupa pengkategorian magic sebagai pantomim, penerapan syarat limited protection variety arts, dan perlindungan trik magic dengan penafsiran hak moral.

\section{Abstract}

The limitation of the form of creation protected in copyright law results in the status of works of magic being difficult to categorize even though in its development the magic is often categorized as drama or choreography, but the elements in that form do not represent magic. Protection is needed because of cases of exposure to magic tricks, while copyright law does not protect the creation in the form of methods. This certainly becomes a legal vacuum. The purpose of this study is to analyze the reconception of legal protection that is right on magic. This research is a normative juridical study with a legal, conceptual, and comparative approach. The results of the study were categorized magic as pantomime, the application of the conditions for limited protection variety arts, and the protection of magic tricks by interpreting moral rights.. 


\section{Rekonsepsi Perlindungan Hukum Atas Magic dalam Perspektif Hukum Hak Cipta di Indonesia}

Ayu Mustika Pamungkas

\section{Latar Belakang}

Industri hiburan kian meningkat dan mengalami perkembangan yang drastis dan statis mengikuti perkembangan dunia. Salah satu hiburan tersebut ialah magic, yang biasa disebut masyarakat Indonesia dengan Sulap. Magic is a performing art that entertains an audience by creating illusions of imposibble or supernatural feats, using purely natural means, these feats called "magic tricks", "effects" or "illusions"(Nelms, 2000) selama berabad-abad magician atau seseorang yang melakukan magic tricks telah melakukan berbagai macam cara untuk memecahkan sebuah 'hukum alam', membuat hal yang dipikir logika tidak mungkin menjadi sebuah hal mungkin yang hasilnya menakjubkan, menebarkan, dan memiliki estetika. Hal inilah yang membedakan magic dengan selainya yang ada di dunia saatini.

Proses pemikiran ide-ide dan menjadikannya sebuah magic patut diapresiasi dan dihormati dan mengkategorikan magic sebagai bagian dari hak kekayaan intelektual yang patut dilindungi oleh hukum. World Intellectual Property Organization (WIPO) memberikan definisi dari HKI, "Intellectual property (IP) refers to creations of the mind: invention, literary and artistic works, symbols, names, images, and designs used in commerce.."(WIPO, 2018) Secara umum dapat dikatakan bahwa obyek yang diatur oleh HKI merupakan karya-karya yang lahir karena kemampuan manusia. Ide-ide tersebut keluar dari fikiran manusia dan menjelma dalam suatu ciptaan sastra, ilmu pengetahuan, dan lainnya makahal itu akan (tangible) dan dapat menjadi sumber keuntungan bagi yang menciptkanya.

Magic dapat dikatakan sebagai hasil dari pemikiran intelektual di bidang seni. Perlindungan terhadap kekayaan intelektual di bidang seni diatur dalam Hak Cipta. Hak cipta merupakan cabang dari HKI yang melindungi ciptaan seseorang dalam aspek ilmu pengetahuan, seni dan sastra. Pengaturan Hak Cipta di Indonesia diatur dalam Undang-Undang Nomor 28 tahun 2014 (selanjutnya dalam penulisan ini disingkat UUHC) dan menjelaskan pengertian hak cipta sebagai berikut:
"Hak Cipta adalah hak eksklusif pencipta yang timbul secara otomatis berdasarkan prinsip deklaratif setelah suatu ciptaan diwujudkan dalam bentuk nyata tanpa mengurangi pembatasan sesuai dengan ketentuan peraturan perundang-undangan."

UUHC mengatur pula terkait bentuk ciptaanciptaan yang dapat dilindungi oleh hak cipta yang diatur pada pasal 40 ayat (1) yaitu: Buku, pamflet, perwajahan karyatulis yang diterbitkan, dan semua hasil karya tulis lain; Ceramah, kuliah, pidato, dan ciptaan lain yang sejenis dengan itu; Alat peraga yang dibuat untuk kepentingan pendidikan dan ilmu pengetahuan; Lagu dan/atau music dengan atau tanpa teks; Drama, drama musikal, tari, koreografi, pewayangan, dan pantomim; Karya seni rupa dalam segala bentuk seperti lukisan, gambar, ukiran, kaligrafi, senipahat, patung, kolase; Karya seni terapan; Karya arsitektur; Peta; Karya seni batik atauseni motif lain; Karya fotografi; Potret; Karya sinematografi; Terjemahan, tafsir, saduran, bungarampai, basis data, adaptasi, aransemen, modifikasi dan karya lain dari hasil transformasi; Terjemahan, adaptasi, aransemen, transformasi, atau modifikasi ekspresi budaya tradisional; Kompilasi Ciptaan atau data, baik dalam format yang dapat dibaca dengan Program Komputer maupun media lainnya; Kompilasi ekspresi budaya tradisional selama kompilasi tersebut merupakan karya yang asli; Permainan video; dan Program Komputer.

Penjelasan bahwa perlindungan hukum hanya diberikan pada ciptaan-ciptaan yang dijabarkan pada pasal 40 ayat (1) huruf a sampai dengan huruf s. Dalam hal ini pengkategorian magic sebagai salah satu ciptaan yang disebutkan dalam pasal 40 ayat (1) masih menjadi sebuah permasalahan. Menurut perkembangan yang ada bahwa magic mungkin dapat dikategorikan sebagai ciptaan yang masuk dalam chorography works atau dramatic works, atau dalam Undang-undang Hak Cipta (Selanjutnya disingkat UUHC) pada pasal 40 magic dapat masuk dalam kategori ciptaan korografi atau drama. Penjelasan mengenai drama atau koreografi sendiri tidak diatur lebih lanjut dalam UUHC. 


\section{Jurnal Cakrawala Hukum, Volume 10 No. 2 Desember 2019}

ISSN PRINT 2356-4962 ISSN ONLINE 2598-6538

Pengaturan copy right (hak cipta) di Amerika Serikat oleh kantor hak ciptanya menjelaskan definisi dari choreography ialah "The composition and arrangement of dance movements and patterns, usually intended to be accompanied by music" (koreografi ialah komposisi dan penataan gerakan dan sebuah poladari tarian, biasanya kegiatan ini dilakukan dengan diiringi oleh musik). Sedangkan dalam Kamus Besar Bahasa Indonesia menjelaskan bahwa koreografi seni mencipta dan mengubah tari atau seni tari. Jika dikaitkan dengan magic hal ini sangat bersebrangan dengan magic, karena magic bukanlah sebuah ciptaan yang menekankan seni atau keindahan yang berasal dari rangkaian gerakan badan.

Begitu pula dengan definisi dramatic works atau drama hal ini juga bersebrangan dengan magic dalam Kamus Besar Bahasa Indonesia, drama merupakan genre (jenis) karya sastra yang menggambarkan kehidupan manusia dengan gerak. Drama menggambarkan realitas kehidupan, watak, serta tingkah laku manusia melalui peran dan dialog yang dipentaskan. Kisah dan cerita dalam drama memuat konflik dan emosi yang secara khusus ditujukan untuk pementasan teater.

Penjelasan tersebut maka dapat disimpulkan bahwa pengkategorian magic ini merupakan masih mengambang. Pengkategorian ciptaan yang dilindungi dalam UUHC seakan memberikan batasan yang terlalu lebar sehinga baik magic ataupun karya lainnya yang tidak dikategorikan dalam UUHC pada pasal 40 ayat (1) berisi ketidak dapatan untuk dilindungi. Padahal mungkin saja syarat perlindungan hak cipta berupa keaslian (originality), berdasarkan kemampuan pikiran, imajinasi (creativity) dan dalam bentuk yang khas (fixation) dapat dipenuhi oleh magic, namun hal ini kemudian bersinggungan kembali karena adanya pengkategorian ciptaan yang dilindungi dalam UUHC.

Permasalah selanjutnya ialah terhadap tindakan pemaparan tricks atas magic hal ini juga mengalami permasalahan hukum, karena trik dalam magic merupakan sebuah metode, cara, atau ide yang bersifat rahasia dan dilindungi oleh penciptanya, namun metode, cara atau ide faktanya tidak dilindungi dalam UUHC, seperti yang diatur dalam pasal 41 UUHC menjelaskan hasilkarya yang tidak dilindungi hak cipta sebagai berikut "Setiap ide, prosedur, sistem, metode, konsep, prinsip, temuan, atau data walaupun telah diungkapkan, dinyatakan, dijelaskan, atau digabungkan dalam sebuah ciptaan"

Penjelasan tersebut dapat disimpulkan bahwa trik magic bukan merupakan hasil karya yang tidak dilindungi hak cipta. Dari permasalahan-permasalahan hukum yang ada tentu hal ini akan mengakibatkan semakin terbukanya kesempatan terhadap tindakan pelanggaran hak kekayaan intelektual atas magic, jika pengaturan yang ada belum secara maksimal melindungi. Oleh karena latar belakang masalah tersebut, peneliti mengangkat rumusam masalah berkaitan dengan, bagaimana rekonsepsi perlindungan hukum atas magic dalam perspektif hukum hak cipta di Indonesia.

\section{Metode}

Penelitian ini merupakan jenis penelitian yuridis normative (normative legal research). Adapun pendekatan penelitian ini ialah pendekatan perundang-undangan(statue approach), pendekatan konseptual (conseptual approach), dan pendekatan perbandingan (comparative approach). Teknik analisis yang digunakan ialah analisis kualitatif dengan interpretasi gramatikal dan interpretasi ekstensif.

\section{Hasil dan Pembahasan}

\subsection{Perbandingan Pengaturan Perlindungan atas Magic Indonesia Dengan Amerika Serikat}

Baik perlindungan UUHC Indonesia maupun dengan perlindungan USC di Amerika atas magic memiliki perbedaan dan persamaan pengaturan. Persamaan secara mendasar ialah: 


\section{Rekonsepsi Perlindungan Hukum Atas Magic dalam Perspektif Hukum Hak Cipta di Indonesia}

Ayu Mustika Pamungkas

a) Bahwa pengaturan hak cipta di Indonesia dan di United States of Amerika Serikat samasama mengakui hak eksklusif yaitu berupa hak moral dan hak ekonomi yang dimiliki pencipta atau pemegang hak cipta;

b) Bahwa berdasarkan pengaturan hak cipta di Indonesia dan United States of Amerika pendaftaran hak cipta bukan merupakan suatu kewajiban/keharusan, karena hak cipta secara otomatis melekat pada suatu hasil karya/ ciptaan pada saat ciptaan tersebut mempunyai bentuk yang nyata/rill. Pendaftaran hak cipta kekantor hak cipta hanya untuk memberikan posisi tawar (bargaining position) yang lebih kuat bagi sipencipta atau pemegang hak cipta apabila terjadi sengketa hak cipta di kemudian hari;

c) Bahwa Indonesia dan United States of Amerika Serikat sama-sama tidak mengakui ciptaan dalan bentuk ide, konsep, metode, atau ciptaan yang tidak ekspresikan dalam bentuk nyata.

Sedangkan perbedaan mendasar tersebut dijelaskan sebagai berikut:

Tabel 1 Perbandingan Perlindungan UUHC dan USC atas magic

\begin{tabular}{|c|c|c|c|}
\hline No & Pembanding & UUHC & USC \\
\hline 1 & Hak Moral & $\begin{array}{l}\text { Bahwa hak moral di Indonesia diberikan } \\
\text { kepada seluruh jenis ciptaan yang dilindungi } \\
\text { hak cipta yang diatur dalam pasal } 40 \text { UUHC, } \\
\text { yang berhak mempertahankan hak moral yang } \\
\text { diatur dalam pasal } 5 \text { UUHC. Dalam hal ini } \\
\text { pencipta atas karya magic ia memiliki hak moral } \\
\text { atas ciptaannya. }\end{array}$ & $\begin{array}{l}\text { Sementara itu pengaturan mengenai } \\
\text { hak moral di Amerika hayalah } \\
\text { diberikan kepada pencipta karya } \\
\text { atau ciptaan visual (visual works) } \\
\text { Sedangkan karya magic di dalam } \\
\text { USC ia tidak memiliki perlindungan } \\
\text { atas hak moral. }\end{array}$ \\
\hline 2 & Ma & $\begin{array}{l}\text { Bahwa masa berlaku hak cipta di Indonesia } \\
\text { dibedakan menurut sifat ciptaan. Hak moral } \\
\text { pencipta sebagaimana yang diatur pada pasal } 5 \\
\text { ayat(1) huruf a,b,e berlaku tanpa batas waktu. } \\
\text { Hak moral pencipta sebagiamana yang di atur } \\
\text { dalam pasal } 5 \text { ayat (1) huruf c dan d berlaku } \\
\text { selama berlangsungnya jangka waktu hak cipta } \\
\text { atas ciptaan yang bersangkutan. } \\
\text { Masa berlaku hak ekonomi, seperti buku, alat } \\
\text { peraga, lagu, music, drama, drama musikan, } \\
\text { tari, koreografi, pewayangan, pantomime } \\
\text { karya senirupa, karya arsitektur, peta, karya } \\
\text { seni motif. berlaku selama hidup pencipta dan } \\
\text { terus berlangsung selama } 70 \text { tahun. Apabila } \\
\text { dimiliki badan hukum } 50 \text { tahun sejak pertama } \\
\text { kali dilakukan pengumuman. Maka dalam hal } \\
\text { ini jika magic di kategorikan ciptaan dalam }\end{array}$ & $\begin{array}{l}\text { Sedangkan masa berlaku hak cipta } \\
\text { di Amerika bervariasi tergantung } \\
\text { pada tanggal pembuatannya/ date } \\
\text { of creation. Untuk ciptaan yang } \\
\text { dibuat sebelum tahun 1978, namun } \\
\text { tidak dipublikasikan yaitu selama } \\
\text { pencipta hidup ditambah } 70 \text { Tahun. } \\
\text { Untuk ciptaan yang di publikasi kan } \\
\text { antara tahun 1923-1963 yaitu selama } \\
28 \text { Tahun dengan opsi untuk } \\
\text { memperbaharui untuk masa } 67 \\
\text { tahun, dan bila tidak diperbaharui } \\
\text { akan masuk dalam public domain. } \\
\text { Untuk ciptaan yang dipublikasi } \\
\text { antara tahun 1964-1977 yaitu } 95 \\
\text { tahun. Untuk ciptaan yang di buat } \\
\text { pada tahun } 1978 \text { atau sesudahnya: }\end{array}$ \\
\hline
\end{tabular}


Jurnal Cakrawala Hukum, Volume 10 No. 2 Desember 2019

ISSN PRINT 2356-4962 ISSN ONLINE 2598-6538

bentuk koreografi atau pantomime maka perlindungannya berlaku seumur hidup dan ditambah 70 tahun.
1) untuk pencipta tunggal yaitu selama pencipta hidup ditambah 70 tahun dan

2) untuk pencipta dalam bentuk perusahaan atau pencipta anonym yaitu 95 tahun sejak publikasi atau 120 tahun sejak pembuatan, manapun yang lebih pendek masanya.

\begin{tabular}{lll}
\hline & $\begin{array}{l}\text { Perlindungan } \\
\text { tahap awal }\end{array}$ & Tidak diatur
\end{tabular}

Sebelum mengkategorikan ciptaan magic dalam sub kategori ciptaan yang dilindungi oleh USC yang diatur dalam 17 USC §102.

Dilakukannya Limited Variety Arts Test. Bahwa karya dibidang variety arts (dalam hal ciptaan magic, circus, atau panggung komedi) Limited Protection Variety Arts Test, meninjau beberapahal, agar magic dapat dilindungi, diantaranya sebagai berikut

1. must be in the form of performance;

2. must have theme;

3. strong charater;

4. plot structure;
Penyelesaian Sengketa yang dilakukan ialah adanya pertimbangan hakim dengan melakukan substantial similarity test, yang substansinya dilihat dari aspek:
1. Action;
2. Property;
3.Setting;
4. Performer;
5. Mistakes;

Penjelasan tersebut, masing-masing baik Indonesia dengan US memiliki kelemahan dan kelebihan dalam perlindungan atas magic. Maka diperlukannya rekonsepsi untuk mengatur perlindungan atas magic yang lebih fokus dan tepat sasaran.

\subsection{Rekonsepsi Perlindungan Hukum atas Magic dalam Perspektif Hukum Hak Cipta}

Perlindungan hak cipta baik dalam perlindungan UUHC Indonesia dengan USC Amerika Serika sama-sama memiliki kekurangan dalam perlindungan hukumnya atas magic. Maka dari hal 


\section{Rekonsepsi Perlindungan Hukum Atas Magic dalam Perspektif Hukum Hak Cipta di Indonesia}

Ayu Mustika Pamungkas

itu perlunya pengkonsepanulang terhadap perlindungan atas magic dalam perspektif hak cipta agar perlindungan tersebut dapat tepat sasaran atau melindungi karya magic dengan baik. Pada dasarnya magic merupakan sebuah karya seni dalam yang dalam pembuatan ciptaannya, seorang pencipta mengorbankan waktu, dana, dan segala usaha agar ciptaan tersebut dapat diakui dan dapat meningkatkan perekonomiannya.

Locke mengatakan dalam teori labour, bahwa manusia berhak menguasai alam dan hasilnya, terutama karena manusia telah bekerja mengolah alam dan untuk itu manusia berhak untuk mendapatkan atau memiliki hasil olahan atas alam tersebut. Hasil kerja manusia adalah milik manusia tersebut. Disini dikatakan pula oleh Locke, ketika manusia telah mencampur pekerjaannya dengan hasil alam, maka hasil tersebut ialah miliknya, karena manusia telah mengeluarkan keringat atas hasil kerja keras dan juga pencampuran dengan kerja manusia, maka manusia berhak memiliki hasil tersebut (Haryanto, 2014) dan hal inilah yang menjadi dasar bahwa karya seseorang dalam hal ini ciptaan magic maka ia berhak untuk mempertahankan apa yang menjadi kepemilikannya.

Berdasarkan pada penjelasan tersebut maka untuk mempertahankan kepemilikan sangat diperlukannya perlindungan hukum. Perlindungan hukuma dalah perlindungan akan harkat dan martabat, serta pengakuan terhadap hak-hak asasi manusia yang dimiliki oleh subyek hukum berdasarkan ketentuan hukum dari kesewenangan atau sebagai kumpulan peraturan atau kaidah yang akan dapat melindungi suatu hal dari hal lainnya. Berkaitan dengan konsumen, berarti hukum memberikan perlindungan terhadap hak-hak pelanggan dari sesuatu yang mengakibatkan tidak terpenuhinya hak-hak tersebut (Hadjon, 1987).

Rekonsepsi perlindungan tersebut oleh peneliti di bagi menjadi dua upaya perlindungan hukum atas magic ialah dengan sarana perlindungan hukum preventif dan represif. Perlindungan preventif ialah perlindungan yang diberikan oleh pemerintah dengan tujuan untuk mencegah sebelum terjadinya pelanggaran. Hal ini terdapat dalam peraturan perundang-undangan dengan maksud untuk mencegah suatu pelanggaran serta memberikan ramburambu atau batasan dalam melakukan suatu kewajiban. Sedangkan perlindungan hukum represif merupakan perlindungan akhir berupa sanksi seperti denda, penjara, dan hukuman tambahan yang diberikan apabila sudah terjadi sengketa atau telah dilakukan suatu pelanggaran. Rekonsepsi perlindungan atas magic dalam perspektif hak cipta, dijelaskan sebagai berikut:

\section{Sarana Perlindungan Secara Preventif}

Konsep pertama, dalam sarana perlindungan preventif ialah perlunya membedakan antara karya magic, terhadap common magic atau professional magic. Menurut peneliti tidak semua magic dapat dilindungi dalam perspektif hak cipta pengkategorian magic atas common magic atau professional magic merupakan tahap pada persyaratan dari hak cipta itu sendiri yaitu orisinil, karena karakteristik pada common magic merupakan hal yang sudah menjadi public domain. Pembeda antara common magic dan professional magic dijelaskan sebagai berikut:

Jadi dalam perlindungan hak cipta, hanya pertunjukan pada professional magic dalam Stage Illusion yang dalam dilindungi, common magic tidak, karena kebanyakan common magic telah menjadi public domain. Syarat orginalitas dapat terpenuhi pada professional magic karena unsur factor pembeda dengan ciptaan magic merupakan hal yang penting diperhatikan untuk orang-orang yang menggeluti profesi sebagai magician 
Jurnal Cakrawala Hukum, Volume 10 No. 2 Desember 2019

ISSN PRINT 2356-4962 ISSN ONLINE 2598-6538

Tabel 2 Common Magic dan Professional Magic

\begin{tabular}{|c|c|c|c|}
\hline No & Pembeda & Common Magic & Professional Magic \\
\hline 1. & $\begin{array}{l}\text { Proses } \\
\text { Penemuan }\end{array}$ & $\begin{array}{l}\text { Penemuan common magic dapat } \\
\text { dipelajari dengan mudah, de- } \\
\text { ngan cara belajar dengan buku, } \\
\text { tutorial umum yang ada di } \\
\text { website, trik yang dapat di beli } \\
\text { toko- took magic. }\end{array}$ & $\begin{array}{l}\text { Penemuan di perlukan dalam waktu yang lama, } \\
\text { dan latihan magic untuk dipertunjukan kepada } \\
\text { public bisa mencapai waktu bertahun-tahun. Bebe- } \\
\text { rapa diantaranya harus bergabung dengan komu- } \\
\text { nitas magic dan selain itu perkembangan zaman } \\
\text { bahkan orang yang ingin focus dalam professional } \\
\text { magic ia harus menjadi murid di sekolah magic. }\end{array}$ \\
\hline 2. & Pertunjukan & $\begin{array}{l}\text { Pertunjukan common magic ti- } \\
\text { dak serumit dengan professional } \\
\text { magic, sasaran petunjukannya } \\
\text { hanya dalam skala kecil, atau } \\
\text { bahkan tidak dipertunjukan, } \\
\text { orang-orang yang menggemari } \\
\text { common magic biasanya hanya } \\
\text { melakukannya untuk rasa pe- } \\
\text { nasaran atau melampiaskan } \\
\text { rasa 'iseng' yang bersifat hobi. }\end{array}$ & $\begin{array}{l}\text { Pertunjukannya dilakukan dengan lebih serius, } \\
\text { rumit dan terstruktur. Biasanya bagi seseorang } \\
\text { yang menggeluti bidang professional magic ia } \\
\text { melakukan penulisan skrip atau rentetan-rentetan } \\
\text { pertunjukan magic yang nantinya ia tampilkan } \\
\text { keumum. Skala pertunjukan tergolong lebih besar. } \\
\text { Biasanya pertunjukan membutuhkan tim yang } \\
\text { akan membantu jalannya pertunjukan. } \\
\text { Walaupun beberapa trik mungkin telah sering } \\
\text { digunakan oleh entertain magic lainnya. Namun, } \\
\text { dalam pertunjukannya magician harus memiliki } \\
\text { faktor yang memebedakan pertunjukannya de- } \\
\text { ngan orang lain, sepertihalnya penambahan } \\
\text { drama, atau scenario cerita dalam pertunjukkan- } \\
\text { nya, menggunakan property khusus yang berkait- } \\
\text { an dengan scenario cerita yang akan di tampilkan, } \\
\text { atau penampil harus memiliki stage personality } \\
\text { beda dengan yang lain. Seperti karakter pendiam, } \\
\text { dingin, atau karakter misterius. }\end{array}$ \\
\hline 3. & Profesi & $\begin{array}{l}\text { Seseorang yang menggeluti } \\
\text { common magic tidak } \\
\text { beranggapan magic merupakan } \\
\text { lahan pencarian ekonominya, } \\
\text { atau bukan digeluti sebagai } \\
\text { profesi. }\end{array}$ & $\begin{array}{l}\text { Seseorang yang menggeluti bidang magic } \\
\text { beranggapan bahwa magician ialah sebagai } \\
\text { sebuah profesi, yang mana ia akan mendapatkan } \\
\text { nilai ekonomis dari pertunjukan magic yang ia } \\
\text { ciptakan dan ia pertunjukan. }\end{array}$ \\
\hline 4. & Perlengkapan & $\begin{array}{l}\text { Perlengkapan dalam common } \\
\text { magic tergolong sederhana dan } \\
\text { dapat ditemukan di toko- } \\
\text { tokomagic. Seperti kartu }\end{array}$ & $\begin{array}{l}\text { Perlengkapan yang dibutuhkan merupakan per- } \\
\text { lengkapan yang menjadi penunjang dalam per- } \\
\text { tunjukan dan sangat berkaitan dengan teman } \\
\text { pertunjukan yang akan di tunjukan. } \\
\text { Perlengkapan professional magic biasanya dibuat } \\
\text { secara khusus. }\end{array}$ \\
\hline 5. & Genre & $\begin{array}{l}\text { Common magic tidak memiliki } \\
\text { genre dalam pertunjukannya. } \\
\text { Ia hanya mengandal kantrik- } \\
\text { trik sederhana dan } \\
\text { perlengkapan yang mudah } \\
\text { ditemui. }\end{array}$ & $\begin{array}{l}\text { Professional magician cenderung memilih genre da- } \\
\text { lam magic performance. Typology magic performance } \\
\text { bisa dalam bidang, ilusi, close-up magic, men- } \\
\text { talism, bizzare magic, atau fakir magic. Karena } \\
\text { pelatihan terhadap trik-trik setiap genre memiliki } \\
\text { waktu yang lama untuk di pelajari sampai } \\
\text { akhirnya bisa dilakukan secara sempurna. Dalam } \\
\text { penelitian ini perlundungan hanya terfokus dalam } \\
\text { magic performance untuk stage illusion. }\end{array}$ \\
\hline
\end{tabular}




\section{Rekonsepsi Perlindungan Hukum Atas Magic dalam Perspektif Hukum Hak Cipta di Indonesia}

Ayu Mustika Pamungkas

Konsep kedua, ialah menerapkan syarat Limited Protection Variety Arts, guna meninjau magic yang dapat dilakukan perlindungan terhadapnya. Dari segimust be in the form of performance (dalam hal ini magic harus berbentuk sebagai pertunjukan, hal ini bertujuan untuk sebagai sarana publikasi), must have theme (dalam hal ini berkaitan dengan pertunjukan magic harus mempunyai tema atau karakteristik yang khas, hal ini berkaitan dengan orisinalitas suatu karya), strong charater ( artinya ialah tidak hanya melihat objeknya saja, tetapi penampil yang menampilkan magic ialah harus mempunyai karakter yang kuat, hal ini juga masih berkaitan dengan orisinalitas), dan terakhir plot structure (dalam hal ini pertunjukan magic, ialah harus mempunyai alur atau pokok cerita yang terstruktur).

Ketiga, Menurut peneliti, penulisan skrip ini berguna untuk pembuktian sebuah keorginalitasan pertunjukan magic. Kerahasiaan magic tricks tetap dijaga dan tidak perlu di tulis dalam skrip, skrip ini dapat berisikan tentang Identitas magic performance sepertihalnya Judul (nama pertunjukan), Identitas Pencipta, Waktu Pembuatan, Skenario Aksi Panggung, Data Pelaku-pelaku Pertunjukan, Properti yang digunakan, serta Sejarah pertunjukan dari magic performance tersebut. Penulisan skrip, dilakukan oleh Teller (United States District Court, District Of Nevada, Teller v. Dogge, 2012) sebagai salah satu contoh dari karyanya yang terkenal yaitu Shadow dan terbukti berhasil sebagai bukti yang valid di muka persidangan penyelesaian sengketa.

Keempat, ialah pendaftaran. Benar adanya bahwa perlindungan atas hak cipta timbul secara otomatis sesuai dengan prinsip deklaratif sesuai yang diatur dalam pasal 1 angka 1 UUHC. Pendaftaran adalah perbuatan hukum yang diatur dalam undang-undang HKI suatu negara dan konvensi-konvensi internasional tetang HKI. Dalam hubungannya dengan HKI, pendaftaran adalah kegiatan pemeriksaan dan pencatatan setiap karya intelektual seseorang oleh pejabat pendaftaran, dalam buku daftar yang disediakan untuk itu, berdasarkan permohonan oleh pemilik atau pemegang hak, menurut syarat-syarat dan tata cara yang diatur undang-undang, dengan tujuan untuk memperoleh kepastian status kepemilikan dan perlindungan hukum. Sebagai bukti pendaftaran, diterbitkan sertifikat HKI (Muhammad, 2007) Namun, pendaftaran ini memiliki fungsi proteksi yang lebih pasti. Selain itu hal ini bermanfaat guna menjaga keoriginalitasan terhadap suatu ciptaan. Dianjurkan kepada pencipta maupun pemegang hak cipta untuk mendaftarkan ciptaanya. Itu juga termasuk hal penting karena, surat pendaftaran ciptaan tersebut dapat dijadikan sebagai alat bukti awal di pengadilan jika terjadinya sengketa dikemudian hari terhadap ciptaan atas magic.

Menurut Marian Darus, pendaftaran itu tidak hanya semata-mata mengandung untuk memberikan alat bukti yang kuat, namun juga menciptakan hak kebendaan. Hak kebedaan atas suatu benda untuk umum terjadi pada saat pendaftaran itu dilakukan. Selama pendaftaran belum terjadi, hak hanya mempunyai arti terhadap para pihak pribadi dan umum dianggap belum mengetahui perubahan status hukum atas hak yang dimaksud. Pengakuan dari masyarakat baru terjadi pada saat hak tersebut di daftarkan (Saidin, 2015)

Ciptaan yang tidak dapat di daftarkan ialah:

a. Ciptan diluar bidang ilmu pengetahuan, seni dan sastra;

b. Ciptaan yang tidak orisinil;

c. Ciptaan yang tidak diwujudkan dalam bentuk nyata;

d. Ciptaan yang telah menjadi public domain (milik uтum)

Maka dari hal ini, konsep perlindungan dalam hal untuk mendaftarkan hak cipta memangbukan kewajiban mengingat perlindungan hak cipta bersifat automaticly protection semenjak magic performance tersebut diumumkan, namun pendaftaran hak cipta juga memiliki peranan penting untuk memberikan proteksi ganda. 


\section{Jurnal Cakrawala Hukum, Volume 10 No. 2 Desember 2019}

ISSN PRINT 2356-4962 ISSN ONLINE 2598-6538

\section{Sarana Perlindungan Secara Represif}

Pertama, ialah berkaitan dengan pengakategorian jenis ciptaan atas magic. Perlindungan atas magic dalam perspektif hak cipta dapat dikategorikan sebagai ciptaan dalam bentuk Pantomim. Hal ini diatur dalam pasal 40 ayat (1) huruf d. Seperti yang dijelaskan sebelumnya, koreografi didefinisikan sebagai"the compositionand arrangement of dance moevements and patterns... usually intended to be accompanied by music."(koreografi ialah komposisi dan pengaturan gerakan dan sebuah bentuk poladaritarian, biasanya dimaksudkan untuk diiringi oleh musik), sedangkan tari atau"Dance is defined of bodily movement in certain rhythmic and spatial relationships.." dan sedangkan karya dalam bentuk Pantomimes, "the art imitating or acting out situations, characthers, or some other events with gestures and body movement... pantomimes need not tell a story" (Pantomim merupakan seni memeragakan atau meniru atau memerankan sebuah situasi, karakter, atau dalam bentuk lain seni dengan gesture atau gerakan tubuh, dan pantomime tidak memerlukan penggambaran sebuah cerita) (Brancolini, 2014).

Kesimpulannya ialah, dibanding menyebutkan magic sebagai karya dalam bentuk dramatic atau choreography works, pemilihan pantomimes sebagai kategori untuk magic lebih tepat untuk merepresentasikan unsur dari magic itu sendiri. Itu mengapa dibutuhkannya pembatasan perlindungan seperti halnya syarat Limited Protection Varierty Arts dalam hal adanya sebuah plot structure untuk menjelaskan alur atau cerita yang digambarkan dalam magic performance tersebut. Tentu perlindungan ini sekali lagi hanya focus terhadap perlindungan pada bentuk stage illusion, yang memiliki plot structure.

Kedua, hak eksklusif berhak didapatkan oleh pencipta atau pemegang hak cipta ialah hak ekonomi dan termasuk pula hak moral. Meskipun dalam USC hak moral hanya diberikan kepada ciptaan tertentu (tidak diberikan dalam ciptaan berbentuk pantomime dalam hal ini ialah magic performance). Menurut peneliti hak moral tidak dapat dipisahkan dari ciptaan tersebut. Pencipta berhak untuk dicantumkan Namanya dalam ciptaan dan hak pencipta untuk melarang orang lain mengubah ciptaannya termasuk judul atau unsur lain dalam ciptaanya. Hak moral merupakan hak yang melekat secara abadi pada diri pencipta, seperti tetap mencamtumkan atau tidak mencamtumkan namanya pada salinan sehubungan dengan pemakaian ciptaannya untuk umum, Menggunakan nama aslinya atau samarannya, Mengubah ciptaanya sesuai dengan kepatuan dalam masyarakat, Mengubah judul dan anak judul ciptaan; dan Mempertahankan haknya dalam hal terjadi distorsi ciptaan, mutilasi ciptaan, modifkasi ciptaan, atau hak bersifat merugikan kehormatan diri atau reputasinya.

Serta juga memperoleh perlindungan dalam hak ekonomi, untuk melakukan hal seperti Penerbitan ciptaan; Penggandaan ciptaan dalam segala bentuknya; Penerjemahan ciptaan; Pengadaptasian, pengaransemenan, atau pentransformasian ciptaan; Pendistribusian ciptaan atau salinannya; Pertunjukan ciptaan; Pengumuman ciptaan; Komunikasi ciptaan; dan Penyewaan ciptaan.

Selain itu dalam perkembanganya karena magic performance merupakan pertunjukan seni, yang mana dalam pertunjukannya juga melibatkan orang lain sebagai penampil atau seseorang yang terlibat dalam hal publikasi dari magic performance tersebut juga berhak mendapatkan perlindungan atas Hak Terkait (neighbouring right). Hak terkait adalah hak yang berkaitan dengan hak cipta yang merupakan hak eksklusif bagi pelaku pertunjukan, producer fonogram atau Lembaga penyiaran. Hak terkait yang dimaksudkan ialah seperti aktor, penyanyi, pemusik, penari atau mereka yang mempertunjukan, menampilkan, memperagakan mendeklamasikan, atau memainkan suatu karya musik, drama, tari, atau dalam hal ini ialah Pantomim atas magic performance. 


\section{Rekonsepsi Perlindungan Hukum Atas Magic dalam Perspektif Hukum Hak Cipta di Indonesia}

Ayu Mustika Pamungkas

Perlindungan yang diberikan terhadap pemegang neighboring right adalah:

1. Hak moral

Hak moral dalam hak cipta disebut sebagai hak yang bersifat asas sebagai natural right yang dimiliki manusia. Dengan demikian sudah merupakan suatu kewajiban bahwa setiap pelaku pertunjukan, produser fonogram dan lembaga penyiaran harus mendapatkan pengakuan dan perlindungan terhadap hak moral yang terlekat dengan karya ciptaan. Hak moral hak terkait diatur dalam pasal 21 UUHC yaitu hak yang melekat pada pelaku pertunjukan yang tidak dapat dihapus dengan alas an apapun walaupun hak ekonominya telah dialihkan. Sehingga dapat diketahui hak moral tidak hanya diberikan bagi pencipta suatu karya tapi juga pada pemegang neighboring right. Selain itu neighboring right dalam magic performance juga berkaitan dengan Produser fonogram, adalah seorang atau badan hukum yang pertama kali merekam dan memiliki tanggungjawab untuk melaksanakan perekaman suara atau perekaman bunyi, baik perekaman pertunjukan atau maupun perekaman suara atau bunyi lain. Kemudian juga terkait dengan Lembaga Penyiaran dalam hal ini ialah Stasiun TV yang pertama kali melakukan pengumuman/ menunjukan atas magic performance. selain 3 subjek tersebut, terdapat subjek lain seperti halnya confederate yaitu relawan yang biasanya diajak bermain dalam magic performance oleh magician.

2. Hak Ekonomi

Subjek hak terkait pada neighboring right, juga mendapatkan hak ekonomi, pada subjek pelaku pertunjukan hak ekonomi diatur dalam pasal 23 UUHC. Sedangkan subjek produser fonogram hak ekonominya diatur dalam pasal 24 UUHC. Kemudian hak ekonomi pada Lembaga penyiaran dalam hal ini Stasiun TV yang mengumumkan pertama kali magic per- formance hak ekonominya diatur dalam pasal 25 UUHC. Ketiga, dalam hal terjadinya sengketa terkait dengan pelanggaran hak cipta yaitu plagiat atau biasanya yang disebut copycat. Perlunya pengadilan menerapkan substantial similarity test atas magic performance asli dengan magic performance milik terduga pelanggar hak cipta. Substantial similarity test ini yang nantinya akan meninjau beberapa substansi kemiripan yang dilihat dari beberapa substansi sebagai berikut:

1. Action

Dalam hal ini hakim akan melakukan memperbandingkan aksi panggung yang berhubungan dengan tingkah laku, gimik, atau adegan yang dilakukan oleh seorang performer (dalam hal ini ialah magician) secara step by step dengan terduga copyright infringement.

2. Property Ketika dalam hal pertunjukan tersebut dilakukan, maka terdapat hal yang membuat pertunjukan tersebut berbeda dengan yang lain, yaitu ialah property atau perlengkapan atau alat-alat penunjang yang digunakan (ditampilkan) di dalam pertunjukan memiliki kemiri pandengan terduga copyright infringement.

3. Setting Selain itu pengaturan mengenai tata panggung juga perlu di perhatikan, contohnya, tata penempatan propertys, lighting, alur cerita atau plotdan hal lain yang dapat menunjukan perbedaan dalam penampilan satu dengan yang lain.

4. Performer

Performer atau penampil, dalam hal ini yang diperhatikan ialah dari substansi, jumlah penampil dalam sebuah pertunjukan, kemiripan costume, atau menunjukan kemiripan karakter yang sama. 


\section{Jurnal Cakrawala Hukum, Volume 10 No. 2 Desember 2019}

ISSN PRINT 2356-4962 ISSN ONLINE 2598-6538

\section{Mistakes}

Selain itu, dalam sebuah pertunjunkan kesalahan atau human error sering terjadi, dalam hal ini kemungkinan yang terjadi ialah bahwa seseorang yang melakukan copyright tinfringement bisa saja juga meniru kesalahan yang terjadi pada pertunjukan yang asli. Biasanya kesalahan itu merupakan human error yang tidak disengaja ditunjukan dalam pertunjukan akan tetapi tidak mempengaruhi efek entertaining dari pertunjukan tersebut.

Dari rekonsepsi tersebut, diharapkan bahwa perlindungan hukum atas magic dalam perspektif hak cipta dapat tercapai dan tepat sasaran sebagai mana mestinya, karena pada dasarnya perlindungan hukum merupakan hak asasi oleh seluruh umat manusia untuk mempertahankan apa yang menjadi kepemilikannya.

\section{Simpulan}

Perlindungan hukum terhadap magic dari Indonesia dan Amerika Serikat sama-sama memiliki kekurangan dan kelebihan. Maka dari hal itu perlunya merekonsepsi ulang terhadap perlindungan atas magic dalam perspektif hukum hak cipta mengingat magic merupakan salah satu seni dalam bentuk pertunjukan yang patut dilindungi. Upaya perlindungan di bagi menjadi dua yaitu upaya preventif dan represif. Untuk upaya perlindungan preventif ialah perlunya terlebih dahulu harus membedakan karya magic dalam golongan common magic atau professional magic, tujuanya untuk memastikan sifat orisinil yang harus dimiliki oleh suatu ciptaan. Kedua, pemberlakuan Limited Protection Variety Arts, ketiga penulisan skrip, keempat pendaftaran. Perlindungan Represif, pertama pengkategorian ciptaan atas magic sebagai karya di bidang Pantomim, kedua hak eksklusif berhak di dapatkan pencipta atau pemegang hak cipta atas hak ekonomi dan hak moral. Ketiga dilakukannya substantial similarity test atas magic jika terjadi sengketa hak cipta.

\section{Daftar Pustaka}

Gabriel, Godoy-Dalmau. 2017. Substantial Similarity: 'Kohus' Got it Right. Micigan. University of Micigan Law School. Volume 6. Issue 2.

Hans, Michael. 2018. Esensi Perlindungan Hak Cipta atas Karakter Fiktif. Mimbar Yutitia. Vol.2 No.1.

Hidayah, Khoirul. 2017. Hukum Hak Kekayaan Intelektual. Malang. Setara Press.

Janna, Brancolin. 2014. Abracadabra! - Why Copyright Protection for Magic is Not Just An Illusion. Los Angeles. Layola Marymount University and Layola Law School.

Lamont, Peter \& Jim Steinmeyer. 2018. The Secret history of magic: the true story of the deceptive art. New York USA. Tarcher Perigee.

Loshin, Jacob. 2008. How Magician Protect Intellectual Property Without Law. Durham. NC. Carolina Academy Press.

Marzuki, Peter Mahmud. 2017. Penelitian Hukum: Edisi Revisi. Jakarta. Kencana Prenada Media.

Mertokusumo, Soedikno. 2014. Penemuan Hukum: Sebuah Pengantar. Yogyakarta. Cahaya Atma.

Nasution, Rahmi Jened Parinduri. 2013. Interface HukumKekayaanIntelektual dan HukumPersaingan (Penyalahgunaan HKI). Jakarta. Rajawali Press.

Sara, J. Crasson. 2012. The Limited Protections of Intellectual Property Law for the Variety Arts: Protecting Zacchini, Houdini, and Cirque du Soleil. Article Villanova. Pennsylvania. United States. Villanova University Charles Widger School of Law. Vol. 19. Issue 8.

Tim Lindsley, dkk. 2006. Hak Kekayaan Intelektual Suatu Pengantar. Bandung. Alumni. 